\title{
PAJAK DAN RETRIBUSI PARKIR TERHADAP PAD KOTA BANDAR LAMPUNG TAHUN 2014-2018 DALAM EKONOMI ISLAM
}

\author{
Ulul Azmi Mustofa, Novita Purnama Sari \\ Universitas Islam Negeri Raden Intan Lampung \\ ululazmimsi@gmail.com
}

\begin{abstract}
Parking tax and retribution tax as one of the regional income.So that the tax revenue and parking retribution must be maximized. The purpose of this study is to look at the contribution of parking tax and retributionto PAD in Bandar Lampung city in the 2014-2018 period. and to see the effect of parking taxes and levies on local revenue in the perspective of Islamic economics. The method used in this research is quantitative descriptive use data in 2014-2018 period.The results of this study are the contribution of parking tax and retribution to the Bandar Lampung City PAD in 2014-2018 is very less with an average contribution ratio of $1.67 \%$ for Parking Tax and 1.03\% for Parking retribution.In Islamic economics the allocation of parking taxes and parking fees is in accordance with Islamic principles of justice, responsibility and transparency.
\end{abstract}

Key Word:Parking tax, Parking retribution, PAD, Islam

\begin{abstract}
Abstrak
Pajak dan Retribusi parkir sebagai salah satu pendapatan daerah. Sehingga Pendapatan Pajak dan Retribusi parkir harus dimaksimalkan. Tujuan dalam penelitian ini untuk melihat kontribusi pajak dan retribusi parkir terhadap PAD di kota Bandar Lampung periode 2014-2018 dan melihat pengaruh pajak dan retribusi parkir terhadap pendapatan asli daerah dalam prespektifekonomi Islam.Metode yang digunakan dalam penelitian ini adalah deskriptif kuantitatif dengan menggunakan data sekunder tahun 2014-2018. Adapun hasil penelitian ini adalah Kontribusi pajak dan retribusi parkir terhadap PAD Kota Bandar Lampung tahun 2014-2018 sangat kurang dengan rasio kontribusi rata-rata persentase 1,67\% untuk Pajak Parkir dan 1,03\% untuk Retribusi Parkir. Dalam Ekonomi Islam pengalokasian pajak parkir dan retribusi parkir sesuai dengan prinsip Islam yaitu keadilan, tanggungjawab serta transparasi.
\end{abstract}

Kata kunci: Pajak Parkir, Retribusi Parkir, PAD, Islam 


\section{A. Pendahuluan}

Pajak memiliki peranan yang sangat penting guna membiayai kebutuhan negara. Pemasukan tersebut sebagai cara untuk kegiatan pembanguna serta penunjang APBD operasional pemerintahan daerahnya. Pendapatan pajak sebagai salah satu pos penerimaan APBD dimulai sejak awal berdirinya Negara ini. ${ }^{1}$ Pajak merupakan salah satu sumber pendapatan Negara yang selalu meningkat dari tahun ke tahun. Klaim ini dibuktikan dengan data APBN yang selalu diterbitkan secara online dari tahun ke tahun. ${ }^{2}$ Hal ini sebagai pemicu agar pemerintah semakin baik dalam meningkatkan pelayanan kepada masyarakat. Begitu juga dengan pelayanan daerah sehingga pelayanan kepada masyarakat daerah dapatmaksimal.

Pajak dan distribusi daerah setidaknya dinaungi oleh Undang-undang yang menjadi dasar dalam pemungutan yaitu Undang-undang nomor 32 tahun 2004 tentang Pemerintah Daerah, undang-undang nomor 33 tahun 2004 tentang Perimbangan Keuangan Antara Pemerintah Pusat dan Pemerintah daerah, yang terakhir adalah Undang-undang nomor 28 Tahun 2009 tentang pajak daerah dan retribusi daerah. ${ }^{3}$

Bukti daerah telah berhasil menyelenggarakan otonomi daerah dibuktikan dengan adanya peningkatan pendapatan asli daerah atau yang sering disebut PAD. Sebaliknya, apabila pendapatan PAD tersebut turun maka pemerintah daerah dianggap tidak maksimal dalam otonomi daerah. Adapun batas minimal perolehan PAD adalah 20\%. Hal ini merupakan batas minimum dalam menjalankan suatu kegiatan dalam otonomi daerah. Dalam artian jika pendapatan PAD di bawah angka 20\%, maka dianggap daerah tersebut akan tidak masuk kedalam daerah yang mandiri. ${ }^{4}$

Kota Bandar Lampung memiliki PAD di atas 20\%, sehingga kota Bandar Lampung dapat dikategorikan daerah yang memiliki batas minimum.

${ }^{1}$ Krisna Arta Anggar Kusuma dan Putu Wirawat i, "Anallisis Pengaruh Penerimaan Pajak Daerah dan Retribusi Daerah Terhadap Penigkatan PAD Sekabupaten/kota di Provinsi Bali", Ejurnal Akuntansi niversitas Udayana, Vol. 5 No. 3, 2013, hlm 564.

Imam Soebechi, Judicial Review Perda Pajak dan Retribusi Daerah (Jakarta: Sinar Grafika, 2012) hlm 139

${ }^{3}$ Rahmawati Widya Putri, “Analisis Kontriibusi Retrubusi Parkir Terhadap Pendapatan Asli Daerah Kabupaten Malang", JESP-Vol 8 No 1 Maret 2016. Hlm. 24

4Damas Dwi Anggoro, Pajak Daerah dan Retribusi Daerah (Malang: UB Press, 2017) h. 19. 
Bahkan PAD Bandar Lampung mencapai $78,18 \%$ pada tahun 2014. Hal ini dapat dilihat terkait penerimaan PAD Kota Bandar Lampung tahun2014-2018:

Tabel 1

Target dan Realisasi PAD

Kota Bandar Lampung tahun 2014-

\begin{tabular}{|l|l|l|l|}
\hline Tahun & $\begin{array}{l}\text { Target PAD } \\
(\mathrm{Rp})\end{array}$ & $\begin{array}{l}\text { Realisasi } \\
\text { PAD }(\mathrm{Rp})\end{array}$ & $\begin{array}{l}\text { presentase } \\
(\%)\end{array}$ \\
\hline 2014 & 495.200 .463$. & 387.175 .043$. & 78,18 \\
& 931 & 391 & \\
\hline 2015 & 769.108 .142$. & 394.899 .945$. & 51,35 \\
& 606 & 876 & \\
\hline 2016 & 757.745 .187$. & 483.379 .398$. & 63,79 \\
& 987 & 034 & \\
\hline 2017 & 994.795 .696$. & 622.233 .601$. & 62,55 \\
& 600 & 418 & \\
\hline 2018 & 864.895 .980$. & 551.721 .101$. & 63,79 \\
& 850 & 266 & \\
\hline Rata-Rata & 776.349 .094$. & 487.881 .817$. & 63,93 \\
& 394 & 997 & \\
\hline
\end{tabular}

Sumber : BPPRD Kota Bandar Lampung

Data tersebut menunjukkan realisasi PAD yang dikelola oleh BPPRD

Kota Bandar Lampung di tahun 2014 meningkat sebesar Rp. 287.175.043.391. kemudian, pada2015Rp394.899.945.876, selanjutnya diperiode 2016 ada peningkatan Rp.483.379.398.034, pada tahun 2017 juga meningkat sebesar Rp. 622.233.601.418, selanjutnya di tahun 2018 mengalami penurunan Rp. 551.721.101.266. Jika dilihat dari data tersebut maka PAD Bandar lampung tahun 2014-2018 tidak tercapai. Sedangkan pendapat PAD kota Bandar Lampung juga cenderung fluktuatif.

Potensi Kota Bandar Lampung sangat besar dan beraneka ragam. Hal ini dapat dilihat mulai dari Pariwisata, transportasi, industri, dan sebagainya. Potensi besar tersebut harus ditopang dengan tempat untuk lahan parkir yang pada akhirnyadapat terwujud kemampuan daerah dan memperkuat penerimaan daerah. Untuk mewujudkan kemandirian tersebut maka harus dilakukan upaya-upaya dalam memaksimalkan pendapatan daerah khususnya pengelolaan pajak dan retribusi kota Bandar Lampung. Realisasi pendapatan pajak parkir di daerah Kota Bandar Lampung dari tahun 2014- 2018 adalah sebagai berikut: 
Tabel 2

Realisasi Pajak Parkir, Retribusi Parkir dan PAD

Kota Bandar Lampung Tahun 2014 - 2018

\begin{tabular}{|l|l|l|l|}
\hline $\begin{array}{l}\text { Tahun } \\
\text { Anggaran }\end{array}$ & $\begin{array}{l}\text { Realisasi } \\
\text { Pajak Parkir (Rp) }\end{array}$ & $\begin{array}{l}\text { Realisasi } \\
\text { Retribusi Parkir (Rp) }\end{array}$ & $\begin{array}{l}\text { Realisasi } \\
\text { Pendapatan Asli } \\
\text { Daerah (Rp) }\end{array}$ \\
\hline 2014 & 3.034 .574 .324 & 4.925 .028 .400 & 387.175 .043 .391 \\
\hline 2015 & 3.146 .510 .364 & 5.128 .277 .000 & 394.899 .945 .876 \\
\hline 2016 & $4.070 .125 .335,00$ & 4.306 .501 .000 & 483.379 .398 .034 \\
\hline 2017 & $4.625 .054 .848,00$ & 4.967 .596 .000 & 612.809 .680 .623 \\
\hline 2018 & $6.027 .330 .000,00$ & 4.757 .470 .000 & 551.721 .101 .266 \\
\hline
\end{tabular}

Sumber: BPPRD Kota Bandar Lampung dan Dishub Kota Bandar Lampung, data diolah penulis

Tabel di atas menunjukkan sumber pendapatan yang berdasarkan Pajak dan distribusi parkir naik dari tahun ke tahun. Pemerintah telah berusaha dalam hal meningkatkan pendapatan pajak dan retribusi parkir. Meskipun begitu data tersebut tidak bisa menjadi acuan untuk mengukur keberhasilan kinerja suatu daerah. Karena ada banyak hal untuk menentukan keberhasilan dalam pemungutan pajak dan retribusi parkir baik yaitu dengan melihat pajak parkir dengan profesional, transparan, integritas, serta akuntabilitas. Sehingga pelaksanaan tersebut menjamin bahwa setiap penyelenggaraan kegiatan dapat dipertanggungjawabkan secara terbuka kepada stakeholder.

Islam membolehkan pemerintah mengambil pajak kepada rakyatnya untuk membayar pajak untuk memenuhi kebutuhan pemerintah. ${ }^{5}$ Hal ini disebabkan karena pajak pada dasarnya berfungsi untuk kemaslahatan umat dan untuk menjaga stabilitas kegiatan pemerintahan untuk dapat melakukan fungsi alokasi, distribusi, dan stabilisasi dengan efektif dan efesien. Sehingga penelitian inimengambil judul "Kontribusi Pajak dan Retribusi Parkir terhadap PAD Kota Bandar Lampung Tahun 2014-2018 dalam EkonomiIslam." 


\section{B. Tinjauan Teori}

\section{Pendapatan Asli Daerah (PAD)}

Pendapatan Asli Daerah atau PAD dalam undang-undang nomor 28 tahun 2009 dijelaskan bahwa PAD merupakan sumber keuangan daerah yang digali dari wilayah daerahnya dan terdiri dari hasil pajak daerah, retribusi daerah, pengelolaan keuangan daerah yang dipisahkan, dan pendapatan asli daerah yang sah. ${ }^{6}$

Lain lagi Halim mengartikan bahwa Pendapatan Asli Daerah segala penerimaan daerah yang berasal dari ekonomi asli daerah. Dia juga mengatakan bahwa PAD juga dipisahkan dalam 4 jenis pendapatan yaitu pajak daerah, retribusi daerah, hasil perusahaan milik daerah dan hasil pengelolaan kekayaan milik daerah yang dipisahkan, lain-lain Pendapatan Asli Daerah yang sah. ${ }^{7}$ Sejalan dengan pendapat Halim, Mardiasmo juga mengatakan bahwa PAD adalah penerimaan hasil setoran pajak daerah, retribusi daerah dari milik daerah, hasil pengelolaan kekayaan daerah yang dipisahkan dan lain-lain pendataan asli yang sah. ${ }^{8}$

PAD merupakan pendapatan yang diperoleh pemerintah daerah terkait kegiatan pemerintah daerah, pelayanan kepada masyarakat dan berbagai pemanfaatan sumber daya yang dimiliki pemerintah daerah. Pedapatan ini sebagai salah satu satu indikator dalam tingkat kemajuan suatu daerahsetempat.

Indikator yang digunakan dalam penentuan daerah yang dianggap layak dan tidak layak dilihat dari tingkat ketergantungan suatu daerah terhadap pemerintah pusat. Artinya Semakin tinggi tingkat PAD suatu daerah maka ketergantungan pemerintah daerah terhadap pemerintah pusat dalam hal pendanaan APBDnya akan semakin berkurang disuatu daerah. Artinya pemerintah daerah dilarang untuk melakukan kegitan pungutan kepada masyarakat yang

${ }^{6}$ Feisly Kesek,"Efektivitas dan Kontribusi Penerimaan Pajak Parkir TerhadapPendapatan Asli Daerah Kota Manado", Jurnal EMBA: Jurnal Riset Ekonomi Manajemen BisnisAkutansi Vol 1. No 4, 2013 ISSN 2302-1174. Hlm 1926

7Damas Dwi Anggoro, Pajak Daerah dan Retribusi Daerah... hlm. 45 
menimbulkan high cost economy sehingga akan berdampak pada kurangnya kegiatan di dalam dunia usaha daninvestasi.

Pemahaman dari beberapa pakar terkait PAD dapat ditarik kesimpulan bahwa penerimaan pos teripenting disuatu Negara dimana penerimaan PAD ini bersumber dari pajak daerah, retribusi daerah serta penerimaan pendapatan yang sah yang sesuai dengan Undang-undang yang berlaku. Selain itu juga, Sumber Pendapatan Asli Daerah (PAD) merupakan sumber keuangan daerah yang dapat digali dalam suatu wilayah yang bersangkutan seperti : Pajak Daerah, Retribusi Daerah, Hasil Pengelolaan kekayaan daerah yang dipisahkan dan Lain-lain PAD yang sah.

\section{Pajak Daerah dan Distribusi Daerah}

Beberapa ahli menjelaskan bahwa Pajak Daerah adalah kontribusi wajib pajak kepada daerah yang terutang oleh pribadi atau badan yang bersifat memaksa berdasarkan undang-undang dengan tidak mendapatkan imbalan secara langsung dan digunakan untuk kepntingan daerah demi kemakmuran rakyatnya. ${ }^{9}$

Adapun menurut Damas Pajak Daerah adalah iuran wajib yang dilakukan oleh orang pribadi atau suatu badan kepala daerah tanpa imbalan langsung yang seimbang, yang dapat dipaksakan berdasarkan perundang - undang yang berlaku, yang digunakan untuk membiayai penyelenggaraan pemeritah daerah dan pembangunan daerah. Dapat ditarik kesimpulan bahwa Pajak Daerah adalah iuran wajib setiap warga negara sebagai wujud peran serta warga negara memajukan pembangunan suatu daerah, pengenaannya berdasarkan undang-undang, tidak mendapat imbalan langsung, serta dapat dipaksakan kepada yang melanggar. ${ }^{10}$

Sedangakan Retribusi daerah atau sering disebut pungutan daerah merupakan pembayaran atas jasa atau pemberian izin tertentu yang disediakan oleh pemerintah daerah sebagai sarana untuk kepentingan orang pribadi dan atau badan. Dasar hukum dari 
pajak dan retribusi daerah adalah UU No, 34 Tahun 2000 tentang Pajak Daerah dan Retribusi Daerah dan UU No.28 Tahum 2009.

\section{Pajak Parkir dan Retribusi Parkir}

Para Ahli mendefinisikan Pajak parkir adalah pajak yang dikenakan atas penyelenggaraan tempat parkir di luar badan jalan oleh orang pribadi atau badan, baik yang disediakan berkaitan dengan pokok usaha maupun yang disediakan sebagai suatu usaha,termasuk penyediaan tempat penitipan kendaraan bermotor dan garasi kendaraan bermtor yang memungut bayaran (Ahmad Yani: 2002). Hal ini diperkuat dengan undang-undang No. 28 Tahun 2009 di pasal 62-66 yang menjelaskan bahwa pengelolaan kegiatan perparkiran merupakan salah satu sub system dalam pengendaliaan lalu lintas, dimana efesiensi pengelolaan parkir dapat menciptakan lalu lintas di sebuah kawasan tersebut menjadi lebih tertib danlancar.

Penetapan tarif parkir paling tinggi adalah 30\%.11 Penetapan tarifini telah ditetapkan dengan peraturan daerah. Ketentuan ini dimaksudkan sebagai upaya memberikan kemudahan dan keluwesan kepada pemerintah kabupaten/kota, sehingga dapat disesuaikan dengan kondisi daerah tersebut. Selama tidak menyalahi ketentuan batas atas 30\% maka pemerintah daerah dapat menentukan tarif yang sesuai dengan kondisinya. Adapun secara umum perhitungan pajak parkir adalah: ${ }^{12}$

$$
\begin{aligned}
\text { Pajak Terutang }= & \text { Tarif Pajak } \times \text { Dasar Pengenaan Pajak } \\
= & \text { Tarif Pajak } \times \text { Jumlah } \\
& \text { Pembayaran(uangseharusnya dibayar } \\
& \text { kepada penyelenggara tempatparkir) }
\end{aligned}
$$

Penetapan Retribusi parkir berdasarkan undang-undang No.2 8tahun 2009. Adapun retribusi parkir merupakan suatu kegiatan pembayaran atas jasa atau pelayanan penyediaan

\footnotetext{
${ }^{11}$ Carunia Mulya Firdausy, Kebijakan \& Strategi Peningkatan Pendaoatan Asli Daerahdalam Pembangunan Nasional, ( Jakarta: Yayasan Pustaka Obor Indonesia, 2017), h. 106 ${ }^{12}$ Ibid
} 
tempat parkir yang dimiliki dan dikelola oleh Pemerintah Daerah. ${ }^{13}$ Undang-undang nomor 28 Tahun 2009 juga menjelaskan bahwa retribusi parkir memiliki dua kategori yaitu retribusi jasa umum dan retribusi jasa khusus.

Dilihat dari dua jenis retribusi parkir maka retribusi parkir jasa umum adalah kegitan retribusi pelayanan parkir di Tepi Jalan Umum. Pelayanan parkir di tepi jalan umum sudah ditentukan oleh pemerintah daerah. Sedangkan retribusi parker yang masuk dalam kategori jasa usaha yaitu retribusi parker ditempat khusus parkir.

\section{Pajak dan Retribusi Parkir Dalam Ekonomi Islam}

Pajak adalah suatu keharusan yang ditetapkan terhadap seorang wajib pajak yang harus disetorkan oleh kepala Negara berdasarkan ketentuan tanpa mendapatkan prestasi kembali dari Negara, dan hasilnya untuk membiayai pengeluaran-pengeluaran umum di satu pihak dan untuk merealisasi sebagai tujuan ekonomi, politik, social, dan tujuan yang ingin dicapai oleh Negara.

Dapat dilihat bahwa kegiatan pajak dan retribusi parkir dalam Islam masuk dalam kategori akad Ijarah. Secara bahasa Ijarah adalah upah- mengupah. ${ }^{14}$ sedangkan secara istilah Ijarah adalah penjualan manfaat atau pemindahan hak guna atas suatu barang dan jasa dalam waktu tertentu melalui pembayaran sewa atau upah tanpa diikuti dengan pemindahan kepemilikan barang itu sendiri. ${ }^{15}$ Akad ijarah tidak ada perubahan kepemilikan tetapi hanya perpindahan hak guna saja dari yang menyewakan kepada penyewa.

\section{Metodologi Penelitian}

1. Pendekatan, Jenis, populasi dan Sampel Penelitian

Metode yang digunakan dalam penelitian ini adalah metode deskriptif kuantitatif dengan menggunakan pendekatan

${ }^{13}$ Ibid ... hlm. 203

${ }^{14}$ Hendi Suhendi, Fiqih Muamalah, (Jakarta: Rajawali Pres, 2010), h. 113

15Sayyid Sabiq, Figh Sunnah, (Jakarta: Pena Pundi Aksara, Cet- 1, 2009), h. 150. 
deskriptif. Adapun data yang digunakan dalam penelitian ini adalah menggunakan data primer berupa wawancara dari Dinas Perhubungan dan BPPRD Kota Bandar Lampung. Sedangkan data sekunder di dalam penelitian ini adalah data-data yang berupa catatan, maupun arsip dan sebagainya yang berhubungan dengan hal-hal yang berkaitan tentang pajak parker dan retribusi parker di Kota Bandar Lampung yang didapat dari Dinas Perhubungan dan BPPRD Kota Bandar Lampung.

Populasi dalam penelitian ini adalah data pajak parkir dan retribusi parkir yang berupa data penerimaan realisasi dan target serta data pendapatan asli daerah di Kota Bandar Lampung. Sedangkan sampel yang digunakan adalah data pajak Parkir dan Retirbusi Parkir kota Bandar Lampung dan Dinas Perhubungan Kota Bandar Lampung dari tahun2016-2018.

\section{Metode Analisa Data}

Metode analisis yang digunakan dalam penelitian ini adalah pertama, Membuat tabel target dan realisasi pajak parkir dan retribusi parkir. Kedua, Menyusun tabel analisis kontribusi pajak parkir dan retribusi parkir terhadap PAD. Cara untuk mengetahui berapa besar kontribusi yang dapat disumbangkan dari penerimaan pajak parkir maupun retribusi parkir terhadap PAD Kota Bandar Lampung dengan pendekatan sebagai berikut:

$$
\text { Kontribusi Pajak Parkir }=\frac{\text { Pajak Parkin } \times 100 \%}{\text { Pendapatan Asli Daerah }}
$$

$$
\text { Kontribusi Retribusi Parkir }=\frac{\text { Retribusisi Parkir x } 100 \%}{\text { Pendapatan Asli Daerah }}
$$


Cara untuk menilai kontribusi pajak dan retribusi parkir dapat dilihat pada tabel berikut:

Tabel 3. Klasifikasi Kriteria Kontribusi

\begin{tabular}{|c|c|}
\hline Persentase & Kriteria \\
\hline $0,00 \%-10 \%$ & Sangat kurang \\
\hline $10,10 \%-20 \%$ & Kurang \\
\hline $20,10 \%-30 \%$ & Sedang \\
\hline $30,10 \%-40 \%$ & Cukup baik \\
\hline $40,10 \%-50 \%$ & Baik \\
\hline Diatas $50 \%$ & Sangat baik \\
\hline
\end{tabular}

\section{Analisis Data}

\section{Kontribusi Pajak Parkir terhadap Kota Bandar Lampung}

Pajak Parkir sebagai sumber penerimaan PAD untuk pembiayaan pembangunan daerah, besar kecilnya pendapatan pajak parkir oto,atis akan mempengaruhi kapasitasanggaran suatu aderah baik pembiayai pengeluaran untuk pembangunan maupunanggaran rutin. Sedangkan untuk mengetahui kontribusi pajak parkir peranan penerimaan pajak parkir terhadap Pendapatan Asli Daerah Kota Bandar Lampung pada tahun 2016-2018 dapat dilakukan dengan menggunakan persamaan (Abdul Halim: 2001) sebagai berikut:

\section{Kontribusi $=\frac{\text { Realisasi Pajak Parkir }}{\text { Realisasi penerimaan PAD }} \times 100 \%$}

Artinya semakin besar Pajak Parkir maka akan semakin besar konstribusi terhadap PAD. Sehingga jika dilihat kontribusi Pajak Parkir terhadap PAD pada tahun 2014-2018 adalah sebagai berikut:

Tabel 4

Target dan Realisasi Pajak Parkir Tahun2014-2018 Kota Bandar Lampung

\begin{tabular}{|c|c|c|c|c|}
\hline No. & Tahun & $\begin{array}{l}\text { Target Pajak } \\
\text { Parkir(Rp) }\end{array}$ & $\begin{array}{l}\text { Realisasi Pajak } \\
\text { Parkir (Rp) }\end{array}$ & Presentasi \\
\hline 1 & 2014 & 5.369 .360 .000 & 3.034 .574 .324 & $56 \%$ \\
\hline 2 & 2015 & 6.369 .360 .000 & 3.146 .510 .364 & $49 \%$ \\
\hline 3 & 2016 & 6.369 .360 .000 & 4.070 .125 .335 & $64 \%$ \\
\hline 4 & 2017 & 6.369 .360 .000 & 4.625 .054 .848 & $72.60 \%$ \\
\hline 5 & 2018 & 7.369 .360 .000 & 6.027 .330 .636 & $81.79 \%$ \\
\hline \multicolumn{2}{|c|}{ Rata-rata } & 6.369 .360 .000 & 4.187 .071 .910 & $64.68 \%$ \\
\hline
\end{tabular}


Sumber: BPPRD Kota Bandar Lampung data diolah oleh penulis, 2019

Dapat dilihat pada tabel 4 bahwa penerimaan pajak parkir Kota Bandar Lampung dalam 5 tahun terakhir yakni tahun 2014-2018 belum mencapai target yang telah ditentukan oleh BPPRD Kota Bandar Lampung dengan rata-rata $64,68 \%$. Walaupun belum mencapai target akan tetapi realisasi pajak parkir mengalami kenaikan dari tahun ketahunnya.

Tabel 5

Kontribusi Pajak Parkir terhadap PAD

Tahun 2014-2018 Kota Bandar Lampung

\begin{tabular}{|c|c|c|c|}
\hline Tahun & $\begin{array}{c}\text { Realisasi } \\
\text { Pajak Parkir (Rp) }\end{array}$ & $\begin{array}{c}\text { Pe ndapatan Asli } \\
\text { Daerah (Rp) }\end{array}$ & $\begin{array}{c}\text { Kontribusi } \\
(\%)\end{array}$ \\
\hline 2014 & 3.034 .574 .324 & 387.175 .943 .391 & 0.78 \\
\hline 2015 & 3.146 .510 .364 & 394.899 .945 .876 & 0,80 \\
\hline 2016 & 4.070 .125 .335 & 483.379 .398 .034 & 0,84 \\
\hline 2017 & 4.625 .054 .848 & 622.233 .601 .418 & 0,74 \\
\hline 2018 & 6.027 .330 .636 & 551.721 .101 .266 & 1,09 \\
\hline Rata-Rata & 4.180 .719 .101 & 487.881 .997 .997 & 1,67 \\
\hline
\end{tabular}

Sumber: BPPRD Kota Bandar Lampung data diolah oleh penulis, 2019

Tabel tersebut dapat disimpulakan bahwa kontribusi Pajak Parkir terhadap Pendapatan Asli Daerah Kota Bandar Lampung tahun 2014-2018 memiliki hasil yang berfluktuatif dan tidak melebihi 1,09\% dengan rata-rata yang dimiliki 1,67\%. Dan di tahun 2017 pajak parkir memberikan kontribusi terendah sebesar 0,74\% selama tahun 2014-2018.

\section{Kontribusi Retribusi Parkir terhadap PAD Kota Bandar Lampung}

Selanjutnya Retribusi parkir adalah bagian dari retribusi daerah secara keseluruhan. Salah satu cara untuk mengetahui besarnya kontribusi retribusi parkir Kota Bandar Lampung terhadap pendapatan asli daerah dapat dilakukan dengan cara membandingkan antara jumlah retribusi parkir dengann jumlah pendapatan asli daerah. untuk mengetahui kontribusi retribusi parkir terhadap pendapatan asli daerah (Abdul Halim: 2001) adalah sebagaiberikut:

$$
\begin{aligned}
& \text { Kontribusi }= \text { Realisasi Retribusi Parkir } \\
& \text { x } 100 \% \\
& \text { Pendapatan Asli Daerah }
\end{aligned}
$$


Artinya semakin besar Pajak Parkir maka akan semakin besar konstribusi terhadap PAD. Sehingga jika dilihat kontribusi Retribusi Parkir terhadap PAD pada tahun 2014-2018 adalah sebagai berikut:

Tabel 6

Target dan Realisasi Retribusi Parkir Kota Bandar Lampung Tahun 2014-

\begin{tabular}{|c|c|c|c|c|}
\hline No. & Tahun & $\begin{array}{l}\text { Target Retribusi } \\
\text { Parkir (Rp) }\end{array}$ & $\begin{array}{l}\text { Realisasi Retribusi } \\
\text { Parkir (Rp) }\end{array}$ & $\begin{array}{c}\text { Presentase } \\
(\%)\end{array}$ \\
\hline 1 & 2014 & 6.600 .000 .000 & 4.925 .028 .400 & 0,74 \\
\hline 2 & 2015 & 6.600 .000 .000 & 5.128 .277 .000 & 0,78 \\
\hline 3 & 2016 & 6.600 .000 .000 & 4.306 .501 .000 & 0,65 \\
\hline 4 & 2017 & 6.600 .000 .000 & 4.967 .596 .000 & 0,75 \\
\hline 5 & 2018 & 7.600 .000 .000 & 4.775 .470 .000 & 0.63 \\
\hline \multicolumn{2}{|c|}{ Rata-Rata } & 6.800 .000 .000 & 4.820 .574 .480 & 0,71 \\
\hline
\end{tabular}

2018 2019

SumberBPPRD Kota Bandar Lampung data diolah oleh penulis,

Dapat disimpulkan bahwa realisasi retribusi parkir Kota Bandar Lampung dalam kurun waktu 2014-2018 mengalami fluktuatif setiap tahunnya hal ini disebabkan sifat pemungutan retribusi parkir tidak wajib dan tarif yang diberlakukan diatur oleh kebijakan pemerintah daerah untuk retribusi parkir kota Bandar Lampung tarif parkir diatur oleh Peraturan Daerah Kota Bandar Lampung Nomor 05 Tahun2011.

Tabel 7

KontribusiRetribusiParkirterhadapPADTa hun2014-2018 Kota BandarLampung

\begin{tabular}{|l|l|l|l|l|}
\hline No. & Tahun & $\begin{array}{l}\text { Realisasi Retribusi } \\
\text { Parkir (Rp) }\end{array}$ & $\begin{array}{l}\text { Pendapatan Asli } \\
\text { Daerah(Rp) }\end{array}$ & $\begin{array}{l}\text { Kontribusi } \\
(\%)\end{array}$ \\
\hline 1 & 2014 & 4.925 .028 .400 & 387.175 .943391 & 1,27 \\
\hline 2 & 2015 & 5.128 .277 .000 & 394.899 .945 .876 & 1,29 \\
\hline 3 & 2016 & 4.306 .501 .000 & 483.379 .398 .034 & 0,89 \\
\hline 4 & 2017 & 4.967 .596 .000 & 622.233 .601 .418 & 0,80 \\
\hline 5 & 2018 & 4.775 .470 .000 & 551.721 .101266 & 0,87 \\
\hline \multicolumn{2}{|l|}{ Rata-rata } & 4.820 .574 .480 & 487.881 .997997 & 1,03 \\
\hline
\end{tabular}

Sumber: BPPRD Kota Bandar Lampung data diolah oleh penulis, 2019

Kontribusi Retribusi Parkir terhadap Pendapatan Asli Daerah Kota Bandar lampung dalam kurun waktu 2014-2018. Pada tahun 2014 
kontribusi retribusi parkir sebesar 1,27\% ditahun selanjutnya yakni tahun 2015 sebesar 1,29\% mengalami penurunan. Di tahun 2016 kontribusi retribusi parkir sebesar $0,89 \%$. Di tahun selanjutnyayaknitahun2017sebesar0,80.Danpadatahun2018sebesar0,87\%.

\section{Pendapatan Asli Daerah Kota Bandar Lampung}

PAD dalam Undang-undang No. 33 Tahun 2004, merupakan sumber pendapatan yang berasal dari potensi daerah. Pemerintah daerah dapat mengali sumber pendapatan.

Pendapatan Asli daerah tersebut secara optimal. Berdasarkan data yang diperoleh dari Badan Pengelolaan Pajak dan Retribusi Daerah (BPPRD) Kota Bandar Lampung berikut pemaparan target serta realisasi Pendapatan Asli Daerah Kota Bandar Lampung tahun anggaran2014-2018.

Tabel 8

Target dan Realisasi Pendapatan Asli Daerah Kota Bandar Lampung tahun 2014-2018

\begin{tabular}{|c|c|c|c|}
\hline Tahun & Target PAD (Rp) & Realisasi PAD (Rp) & $\begin{array}{c}\text { presentase } \\
(\%)\end{array}$ \\
\hline 2014 & 495.200 .463 .931 & 387.175 .043 .391 & 78,18 \\
\hline 2015 & 769.108 .142 .606 & 394.899 .945 .876 & 51,35 \\
\hline 2016 & 757.745 .187 .987 & 483.379 .398 .034 & 63,79 \\
\hline 2017 & 994.795 .696 .600 & 622.233 .601 .418 & 62,55 \\
\hline 2018 & 864.895 .980 .850 & 551.721 .101 .266 & 63,79 \\
\hline Rata-Rata & 776.349 .094 .394 & 487.881 .817 .997 & 63,93 \\
\hline
\end{tabular}

Sumber: BPPRD Kota Bandar Lampung data diolah oleh penulis, 2019

Tabel di atas dapat diketahui bahwa Pendapatan Asli Daerah Kota Bandar Lampung pada tahun 2014 memiliki target sebesar Rp. 495.200.463.931 dengan realisasi Rp.387.175.043.391, di tahun 2015 memiliki target sebesar Rp.769.108.142.606 dengan realisasi Rp. 394.899.945.876, ditahun selanjutnya yakni tahun 2016 memiki target sebesar Rp. 757.745.187.987 dengan realisasi Rp. 483.379.398.034, pada tahun 2017 memiliki target Rp. 994.795.696.600 dengan realisasi sebesar Rp. 622.233.601.418. dan pada tahun 2018 target PAD sebesar Rp. 864.895.980.850 dengan realisasi sebesar Rp. 551.721.101.266. Sehingga dapat disimpulkan bahwa penerimaan pendapatan asli daerah dalam kurun waktu 2014-2018 naik tiap tahunnya, hanya saja di tahun 2018 mengalami penurunan. Jika 
dilihat dari presentasi pendapatan asli daerah memiliki rata-rata dalam lima tahun terakhirsebesar 63,93\%.

\section{Kontribusi Pajak dan Retribusi Parkir terhadap PAD ditinjaun dalam} Islam

Pajak dalam Islam dikenal dengan al-Kharaj. Al-Kharaj adalah tanah yang wajib dibayar pajaknya, dengan mulanya tanah itu milik orang kafir yang dibuka secara paksa oleh pasukan kaum muslim kemudian imam menyerahkan kembali tanah itu dengan pemlikinya. Al-Mawardi sebagai ahli ekonomi Islam menjelaskan bahwa dalam Islam pajak dikenal dalam beberapa macam jenis pajak,16 antara lain:
a. zakat.
b. Jizyah,
c. Al-Kharaj,
d. Usry,
e. Barang rampasan perang dan,
f. Pajak hasil pertambangan.

Penetapan tarif pajak dalam hal ini adalah al-Kharaj juga disesuaikan dengan hasil yang dikeluarkan oleh tanah yang terkena pajak, Umar bin Khattab telah menetapkan pajak wilayah Irak untuk setiap lahan seluas satu jarib dan dikenakan Kharaj sebesar satu Qafiz.

\section{E. Hasil dan Pembahasan}

\section{Kontribusi Pajak Parkir terhadap PAD Kota Bandar Lampung}

Sistem pemungutan pajak parkir kota Bandar Lampung mengacu pada Peraturan Daerah kota Bandar Lampung No 1 tahun 2011 tentang pemungutan pajak parkir. Dapat diketahui bahwa kontribusi pajak parkir terhadap pendapatan asli daerah Kota Bandar Lampung dari tahun 20142019 hasilnya berfluktuatif atau naik turun pada tahun 2014 sebesar 0,78\%, di tahun 2015 dan 2016 kontribusi Pajak Parkir mengalami kenaikan sebesar 0,80\% hingga 0,84\%. Akan tetapi di Tahun 2017 kontribusi Pajak Parkir mengalami penurunan sebesar 0,74\% dan pada tahun 2018 kontribusi yang diberikan mengalami kenaikan sebesar 1,09\%. Sehingga bias kita simpulkan 
bahwa kontribusi Pajak Parkir terhadap PAD Kota Bandar Lampung tahun 2014-2018 masuk dalam katagori rendah sekali.

Setelah penulis melakukan wawancara dapat disimpulkan Rendahnya penerimaan pajak parkir disebabkan kegiatan pengelolaan pajak parkir yang dilakukan oleh pemerintah kota Bandar Lampung belum maksimal dalam pengawasan pajak parkir. Kontribusi pajak parkir terhadap pendapatan asli daerah sebaiknya pemerintah terus melakukan upaya mendataan ulang Wajib Parkir (WP) yang belum melakukan pendataan kepada dinas BPPRD dan untuk di tahun berikutnya pemerintah melakukan mendistribusian tapping box di beberapa tempat yang sudah terdaftar sebagai wajib pajak guna meningkatkan penerimaan realisasi pajak parkir di Kota Bandar Lampung karena dengan diadakan tapping box di tempat parkir hal tersebut memudahkan pemerintah dalam memantau berapa jumlah pendapatan yang didapat disetiap harinya, Pajak parkir inilah yang menunjang PAD tinggi ataurendahnya.

\section{Kontribusi Retribusi Parkir terhadap PAD Kota Bandar Lampung}

Kontribusi retribusi parkir terhadap PAD Kota Bandar Lampung periode 2014- 2018 mengalami fluktuatif bahkan mengalami penurunan. Di tahun 2014 kontribusi retribusi parkir sebesar 1,27\% ditahun selanjutnya yakni tahun 2015 sebesar 1,29\% mengalami penurunan di tahun 2016 sebesar 0,89\%. Ditahun selanjutnya yakni tahun 2017 sebesar 0,80 mengalami penurunan pada tahun sebelumnya. Dan pada tahun 2018 adanya peningkatan sebesar $0,87 \%$. Dapat disimpulkan bahwa pada dasarnya kontribusi retribusi parkir terhadap pendapatan asli daerah Kota Bandar Lampung tertinggi terjadi pada tahun 2015 dan pada tahun selanjutnya kontribusi realisasi parkir mengalami penurunan selama 2 tahun.

Berdasarkan hasil wawancara kepada Bapak Afrully Rahmat At, selaku kepala kadiv perparkiran Dinas Perhubungan Kota Bandar Lampung mengatakan "kontribusi retribusi parkir secara menyeluruh mengalami fluktuatif dan adanya penurunan disetiap tahun hal tersebut disebabkan adanya perubahan tren masyarakat dengan berpindah ke transportasi berbasis online, kurangnya kepercayaan masyarakat terhadap upt parkir 
yang bertugas untuk membayar parkir, masyarakat enggan parkir di tepi jalan umm dan memilih parkir di dalam gedung". Dengan hambatanhambatan yang muncul tersebut dilakukan upaya kerjasama dengan intansi pertokoaan, salpol pp, serta patroli rutin untuk mencega terjadinya parkir liar di tepi jalan umum. Menurut penulis retribusi parkir harus adanya pengawasan dan evaluasi terhadap kebijakan yang sudah diimplemintasikan untun menunjang PAD, retribusi parkir bermanfaat untuk masyarakat karena retribusi parkir dapat dijadikan sumber penghasilan masyarakat tentu hal ini bisa mengurangi sedikitnya pengangguran didaerah Kota Bandar Lampung akan tetapi masyarakat yang bekerja sebagai juru parkir wajib menyetorkan hasil pendapatan dengan jujur kepada petugas uptsetempat.

3. Kontribusi Pajak dan Retribusi Parkir terhadap PAD Perspektif Ekonomi Islam

BPPRD kota Bandar Lampung sebagai uli amri dengan penerapan yang telah di tetapkan sudah mempunyai dasar hukum yang sah, yang sudah diatur dan ditetapkan oleh pemerintahan Kota Bandar Lampung. Kedua, jika dilihat prinsip keadilan dalam pemungutan pajak dan retribusi khususnya di bidang perparkiran menerangkan bahwa pajak dan retribusi harus memberikan keadilan. Penerapan prinsip keadilan dalam pemungutan pajak parkir yang di atur BPPRD telah sesuai dengan prinsip adil dalam Islam. Pemungutan pajak parkir ini disesuikan dengan kondisi wajib pajak. Apabila disuatu tempat/Gedung yang menyelenggarakan parkir maka akan di tarik setoran 30\% dari jumlah total wajib pajak sementara dalam retribusi parkir di tepi jalan hasil yang didapat dalam satu hari akan disetorkan kepada upt perparkiran dinasi perhubungan dan tidak ada patokan yang harus disetor dalam retribusi ini. Meskipun demikian dalam pelaksanaan pemungutan pajak dan retribusi parkir harus adanya pengawasan dan transparasi dengan tujuan dapat memastikan bahwa aktivitas berjalan dengan sebagaimana mestinya sehingga kontribusi perparkiran dapat meninggat setiap tahunnya. Akan tetapi dalam praktik tetap saja ada pelanggaran yang terjadi dan tidak jujur dalam melaksanakan 
tugasnya maka dari itu pemerintah harus memberikan sanksi jika ada pelanggran yangmelanggar.

Di Kota Bandar Lampung sanksi yang di dapat jika melakukan kecurangan oleh pemerintah daerah kepada oknum atau wajib pajak (WP) yang tidak menyetorkan pendapatan perparkiran maka akan di dikenakan sanksi, walaupun sanksi tidak sampai dipenjara dan di cambuk akan tetapi akan dikenakan sanksi $2 \%$ dari total pendapatan didapat. ketiga, prinsip transparansi menjadi prinsip penting dalam melaksanakan GCG yang islami, yaitu memeberikan informasi yang akurat dari semua kegiatan dan dapat menjamin teciptanya keadilan dan kejujuran bagi semua pihak. BPPRD dan Dinas Perhubungan telah memberikan informasi dalam transparasi realisasi pendapatan dalam bidang perparkiran sehingga pemerintah benar-benar melakukan pengawasan terhadap sector keuangan dan menjujung tinggi prinsipi kehati-hatian dalam informasi penting. Prinsip yang telah di jelaskan oleh penulis diatas tujuan utama dalam Islam mencapai falah, dengan pencapaian keadilan, sanksi pelanggran serta transaparasi sehingga pendistribusiannya untuk pendapatan asli daerah digunakan untuk memaksimalkan pertumbuhann ekonomi seperti kesehatan, pendidikan dan lain-lain sehingga dapat membantu masyarakat dalam memunuhi kebutuhan hidupnya.

\section{F. Kesimpulan}

Berdasarkan pembahasan maka penulis dapat mengambil kesimpulan sebagai berikut:

1. Kontribusi pajak dan retribusi parkir terhadap PAD kota Bandar Lampung masuk dalam kriteria sangat kurang. Hal ini ditunjukkan pada periode 20142018 dengan rasio kontribusi rata-rata persentase 1,67\% hal tersebut dikarnakan belum mencapai target yangditetapkan.

2. Sementara retribusi parkir dalam klasifikasi kriteria kontribusi dinyatakan masih tergolong sangat kurang dalam kurun waktu 2014-2018 dengan rasio kontribusi retribusi parkir rata-rata persentase 1,03\% hal ini juga disebabkan masih kurangnya pengawasan dalam penarikan retribusi parkir di tepi jalanumum. 
3. Dalam Ekonomi Islam pajak parkir dan retribusi parkir dapat dialokasikan sesuai dengan prinsip Islam dimana pajak parkir dan retribusi parkir dapat memberikan perubahan bagi masyarakat dan pemerintah mampu melakukannya bersama-sama sesuai dengan prinsip syariah yaitu keadilan, tanggungjawab serta transparasi sehingga kontribusi yang didapatkan mencapai sebuah tujuan yang berdasarkan apa yang direncanakan dan apa yang diharapkan untuk kemaslahatanbersama. 


\section{DAFTAR PUSTAKA}

Absor, Ulul, "Analisis Kontribusi dan Efektivitas Retribusi Pasar Terhadap Pendapatan Asli Daerah Kabupaten Brebes", Permana, Vol VI No 1 Agustus 2014.

Arditia, Reza, "Analisis Kontribusi dan Efektivitas Pajak Daerah Sebagai Sumber Pendapatan Asli Daerah Kota Surabaya", Jurnal Universitas Surabaya.

Agus Endro Suarno dan Suhartiningsih, "Efektivitas Evaluasi Potensi Pajak Daerah Sebagai Sumber Pendapatan Asli Daerah", Jurnal Akutansi dan Keuangan, Vol 7 No. 2, 2008.

Bandar Lampung dalam 2018, https:/ / bandarlampungkota.bps.go.id/publication/2018/08/16/ faf88dfb8e10769e3678fd9b/kota-bandar-lampung-dalam-angka2018.html, diakses pada tanggal 12 Oktober 2019.

Carunia Mulya Firdausy, Kebijakan \& Strategi Peningkatan Pendaoatan Asli Daerah dalam Pembangunan Nasional,Jakarta: Yayasan Pustaka Obor Indonesia, 2017

Cholid Narbuko dan Abu Achmadi, Metodologi Penelitian, Jakarta: Bumi Aksara, 2012.

Dwi Anggoro, Damas, Pajak Daerah dan Retribusi Daerah, Malang: UB Press, 2017.

Gusfahmi, Edisi Revisi Pajak Menurut Syariah, Depok: RajaGrafindo Persada, 2017.

Hartono dan Sufia Widi Kasetyaningsih, "Retribusi Jasa Parkir Dalam Pandangan Islam", Suhuf, Vol 30 No. 2, 2016.

Kazwaini, "Epistimologi Perpajakan dalam Pemikiran Al-Mawardi", Jurnal Annida" Pemikiran Islam, Vol. 41 No. 12017.

Kesek, Feisly, "Efektivitas dan Kontribusi Penerimaan Pajak Parkir Terhadap Pendapatan Asli Daerah Kota Manado", Jurnal EMBA: Jurnal Riset Ekonomi Manajemen Bisnis Akutansi Vol 1. No 4, 2013 ISSN 2302-1174.

Krisna Arta Anggar Kusuma dan Putu Wirawati, "Anallisis Pengaruh Penerimaan Pajak Daerah dan Retribusi Daerah Terhadap Penigkatan PAD Sekabupaten/kota di Provinsi Bali", E-Jurnal Akuntansi Universitas Udayana, Vol. 5 No. 3, 2013.

Huda, Nurul, ed. at, Keuangan Publik Pendekatan Instrumen Kebijakan dalam Perspektif Islam, Jakarta: Alex Media Komputindo, 2015.

Mahmudi, Analisis Laporan Keuangan Pemerintah Daerah, Yogyakarta: YPKN, 2016. Mardani, Aspek Hukum Lembaga Keuangan Syariah di Indonesia, Jakarta: Kencana, 2017. Malombeke, Novelia, "Analisis Potensi dan 
Efektivitas Pemungutan Pajak Parkir Di KabupatenMinahasa Utara", Jurnal EMBA, Vol 4 No1 Maret 2016.

Mourin M. Mosal, "Analisis Efektivitas dan Kontribusi Pajak Parkir Terhadap Pendapatan Asli Daerah (PAD) dan Penerapan Akutansi di Kota Manado", Jurnal EMBA Vol 1. No 4 Desember 2013.

Mulya Firdausy, Caruni, Kebijakan \& Strategi Peningkatan Pendapatan Asli daerah dalam Pembangunan Nasional, Jakarta : Yayasan Pustaka Obor Indonesia, cet ke 2, 2018.

Mustafa Edwin Nasution, ed. al. Penngenalan Eksklusif Ekonomi Islam Jakarta: Prenadamedia group, 2015.

Nariana, "Analisis Kontribusi Pajak Parkir terhadap Pendapatan Asli Daerah di Kota Palembang", Jurnal STIE MDP, 2013.

Nurmantu, Pengantar Perpajakan, Jakarta: Granit, 2003.

Pahala Siahaan, Marihot Pajak Daerah dan Retribusi Daerah Edisi Revisi, Jakarta: PT Rajagrafindo Persada, 2013.

Suhendi, Hendi, Fiqih Muamalah, Jakarta: Rajawali Pres, 2010. 